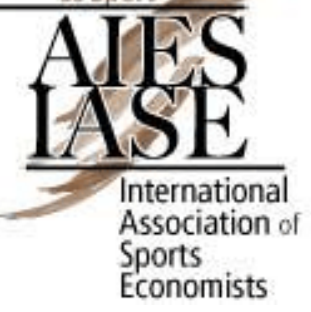

\title{
Gender Differences in Competitive Balance in Intercollegiate Basketball
}

\author{
Jaret Treber ${ }^{\dagger}$, Rachel Levy ${ }^{\dagger \dagger}$, and Victor A. Matheson ${ }^{\dagger \dagger}$
}

October 2011

\begin{abstract}
This paper adds to the literature on competitive balance in college sports by comparing men's and women's NCAA basketball. Using data from the Division I National Championships, we find evidence consistent with the idea that women's college basketball is less competitively balanced than men's college basketball. We argue that this difference may be explained by a theory of player ability borrowed from evolutionary biology first promulgated by paleontologist Stephen Jay Gould and subsequently utilized in Berri (2004). An implication of this idea is that competitive balance in women's NCCA basketball will naturally improve over time. This is good news for those who are concerned with the long term success of the sport to the extent that competitive balance in women's college basketball impacts fan demand. Nevertheless, we discuss why there may be reason to believe that women's college basketball may not reach the same level of balance as men's college basketball.
\end{abstract}

JEL Classification Codes: L83, J16

Keywords: College sports, competitive balance, women's sports, basketball

$\dagger$ Department of Economics, Kenyon College, Gambier, OH 43022, 740-427-5435

(phone), 740-427-5276 (fax), treberj@kenyon.edu

${ }^{\dagger \dagger}$ Bessemer Trust, 900 17th Street NW, Suite 1000, Washington, D.C. 20006, levy@bessemer.com

${ }^{\dagger \dagger}$ Department of Economics, Box 157A, College of the Holy Cross, Worcester, MA 01610-2395, 508-793-2649 (phone), 508-793-3708 (fax), vmatheso@ holycross.edu 


\section{Introduction}

Over the 2008-2009 and 2009-2010 seasons the University of Connecticut (UConn) women's basketball team went 78-0 and captured two National Collegiate Athletic Association (NCAA) national championships. The UConn Huskies exhibited an unprecedented level of dominance, winning every game but one by at least 10 points with an average margin of victory of more than 30 points. ${ }^{1}$ Predictably, UConn's success generated much discussion regarding the team's place in the pantheon of team sports. However, their dominance also spawned debate regarding its impact on the health of women's college basketball. Some believed the attention generated by UConn's streak attracted more fans to women's college basketball. Others argued that fan interest waned as UConn's run greatly diminished the drama associated with the chase for a national championship. Attendance data provides limited insight. During the 2008-2009 and 2009-2010 seasons, per game attendance fell by 1.7 and 1.6 percent respectively, suggesting UConn's reign may have adversely affected interest in the game. Of course such a conclusion may be undermined, at least to some extent, by the fact that these two seasons still registered the third and fourth highest per game attendance averages since the inception of the women's NCAA tournament in 1982.

The underlying issue in this debate is one of the most fundamental topics in sports - the relationship between relative quality and fan demand. Do fans prefer teams to be evenly matched or do they prefer team dynasties? Indeed, the very first paper in modern sports economics, Simon Rottenberg's seminal paper on baseball labor markets, notes early in its introduction that spectator sport is a unique industry in that "competitors must be of

\footnotetext{
${ }^{1}$ By comparison, during their 88 game win streak in the early 1970s the UCLA Bruins men's basketball teams had 16 games decided by less than 10 points and their average margin of victory was 23 points. Scores from each game in UCLA's and UConn's streaks were retreived from http://www.ncaa.com/news/basketball-women/2010-1220/ucla-uconn-road-88-wins on May 20, 2011.
} 
approximately equal 'size' if any are to be successful." (Rottenberg, 1956, pg. 242) This notion was echoed a decade later by Walter Neale who stated that "the economics of professional sports is that receipts depend upon competition among... the teams. 'Oh Lord, make us good, but not that good,' must be their prayer." (Neale, 1964,pg. 2) From these early origins, the study of competitive balance in sports has been of considerable interest to researchers in the field of sports economics.

Numerous authors provide excellent overviews of both the existing literature and the important issues in competitive balance including Sanderson and Siegfried (2003), Zimbalist (2002), and Fort and Maxcy (2003). In general, studies of competitive balance can be categorized into three basic types: 1 . methods for calculating competitive balance; 2 . studies of the effect of competitive balance on attendance and revenues; and 3. the effect of league rules or other factors on competitive balance. It is primarily within this final group in which this paper finds its place.

Most studies of the determinants of competitive balance have focused on league organization including factors such as free agency, revenue sharing, salary caps and floors, reverse order drafts, unbalanced scheduling, and other league rules. Furthermore, the existing literature has focused predominantly on professional sports with only a handful of studies examining competitive balance in college athletics. ${ }^{2}$ Consequently, there remains much to be learned about competitive balance at the collegiate level.

\footnotetext{
${ }^{2}$ Bennett and Fizel (1995), Eckard (1998), Sutter and Winkler (2003), and Depken and Wilson (2004, 2006) examined how changes in various factors including telecast rights and NCAA rules and regulations influenced competitive balance in college football. Quirk (2004) provided evidence suggesting that competitive imbalance may be a determinant of conference realignment in college football. Berri (2004) investigated whether the population of players affects competitive balance in NCAA football, basketball, and baseball. Perline and Stoldt (2007) examined competitive balance in college basketball for the Missouri Valley Conference.
} 
Until the mid-2000s, the literature on competitive balance in college sports focused solely on college football. Berri (2004) expanded the scope of the literature with a comparison of competitive balance in college football, baseball, and basketball. Berri identified differences in competitive balance across these sports and argued that they can be largely attributed to variation in how the professional ranks impact the pool of players available to colleges. Building on Stephen Jay Gould's idea $(1986,1996)$, Berri concludes that "the underlying population of players the sport can employ primarily determines competitive balance" $(2004$, p. 221$)$. This process of identifying and explaining trends and patterns in competitive balance in college sports both within a given sport and across multiple sports is important for improving our understanding of its underlying determinants.

Further expanding the scope of the literature on competitive balance in college sports, this paper examines the effects of gender on competitive balance in intercollegiate sports in the United States. Examining the concentration of championships and performance within the NCAA Division I basketball tournament, we find evidence consistent with the idea that women's college basketball is less competitively balanced than men's college basketball. Similar to Berri (2004), we draw on Gould's work $(1986,1996)$ in developing an explanation for the difference in competitive balance across genders. We argue that competitive balance in men's college basketball improved naturally over time and that the women's game should follow a similar pattern. Given the ever increasing popularity of men's college basketball, this should be welcome news for those concerned with the long term success of women's college basketball. However, we also discuss how the absence of a particular accelerant may prevent women's college basketball from reaching the same level of balance as men's college basketball. 


\section{Measuring Competitive Balance in College Basketball}

\section{The NCAA}

The NCAA is the largest governing body organizing championships in intercollegiate sports and also serves as a rule-making body for its 1,100 member schools. Schools are categorized into one of three divisions in the NCAA based on school size, recruiting rules, athlete eligibility, and the availability of scholarship money for athletes. The highest level of competition is Division I which is made up of 335 schools including large state universities, most of the largest private non-profit universities in the country, and many smaller private and state colleges. Including the different championships held for male and female athletes, 38 championships are sponsored by the NCAA in Division I athletics. Men's and women's basketball are the most commonly offered sports at Division I schools with all Division I schools offering men's basketball and all but three schools sponsoring women's basketball. Basketball is also the most popular women's sport at the collegiate level among spectators, attracting over 8 million fans at the Division I level in 2011. On the men's side, basketball is one of the top two sports (along with football), attracting over 27 million fans in 2011 and generating significant media revenues.

The NCAA has sponsored a national championship in men's basketball since 1939 and in women's basketball since 1982 . The tournaments have taken a variety of formats over these time periods. Most would consider 1985 the beginning of the "modern era" for the men's college basketball tournament. At that time the NCAA expanded the tournament to a 64-team nationally seeded single elimination tournament, and the tournament also experienced a dramatic rise in popularity. The NCAA kept this format until 2001 at which time an additional play-in game was added effectively increasing the field to 65 teams. The men's tournament added three additional 
play-in games in 2011, raising the field to 68 teams. The women's championship grew to a 64team regionally seeded field in 1994 and by 1996 evolved into a 64-team nationally seeded single elimination tournament, just like the men's championship.

In both the men's and women's basketball tournaments, each conference champion is awarded an automatic bid with the remaining tournament slots being filled by at-large teams chosen by a selection committee based on each team's perceived quality.

\section{Methodology}

As described by Humphreys (2002) there are a wide variety of methods to measure competitive balance in part because at least two distinct types of competitive balance exist. Intraseason competitive balance refers to the closeness of competition within any particular season while interseason balance refers to uncertainty of outcome between seasons. For example, in soccer the English Premier League title hunt frequently comes down to the final day of competition with many teams in the chase until late in the season suggesting a strong degree of intraseason balance. In the 16 seasons since 1995, however, only three teams, Manchester United, Chelsea, and Arsenal, have won the championship, and along with Liverpool these "big four" have accounted for 45 of the 48 top three league finishes over this period, indicating a remarkably low level of interseason balance.

Far and away the most commonly used method of measuring intraseason balance in team sports is the standard deviation of win percentage which measures the variability of win percentages between teams in a league. A league with low competitive balance would typically be characterized with a large number of teams with either very high or very low win percentages leading to a high standard deviation of win percentages. This method is both intellectually 
appealing and quantitatively easy to calculate. In addition, the standard deviation of win percentage method can be used to compare the relative competitive balance of leagues with different numbers of teams and, with only slight modification, leagues with different season lengths.

Unfortunately, the standard deviation of win percentage measure is of only limited use in college basketball because of the stratification of teams by conference and the limited amount of interaction between teams from different conferences. In the NCAA, teams are typically organized into conferences with other teams of similar ability, and teams play roughly half of their games against conference opponents, limiting the amount of contact between teams in different conferences. The standard deviation of winning percentage may simply capture the fact that teams are relatively balanced within their own conferences while failing to fully identify the possibility of wide discrepancies in talent between conferences.

In the NCAA tournament, however, the overwhelming majority of matchups involve teams from different conferences. Therefore, measuring the performance of teams in the tournament, in part, gets around the problem of stratification of teams into conferences. In addition, since both tournaments follow similar formats, a comparison of results in the men's and women's tournaments allows one to draw some conclusions regarding the relative competitive balance in men's and women's basketball.

If the talent disparity between a low seed and a high seed is small then the margin of victory should be low and the probability of an upset correspondingly high. Conversely, an unbalanced league should exhibit wider margins of victory between any pair of seeds as well as relatively fewer upsets. Table 1 shows the average margin of victory and the win percentage for teams at each seed for the men's tournament between 1985 and 2011 and the women's 
tournament between 1994 and 2011. As can be seen from the data, first-round games in the women's tournament are far less balanced than in the men's tournament. Upsets occur less frequently at nearly every seed in the women's tournament with the difference being statistically significant in half of the seed pairings in the first round.

Because upsets in earlier rounds cause cascading effects in subsequent rounds, analysis of results in later rounds is problematic; however, the prevalence of upsets can be measured by averaging the values of the remaining seeds at each round. If better seeds win, then the average of the seed numbers at each successive round will remain low while upsets will cause lower ranked seeds to advance, increasing the average of the seed numbers in each round. Table 2 shows the seed averages for the men's and women's tournament for each round along with an "idealized" average of seeds which assumes no upsets. Again, the data show that upsets are less likely throughout the entire women's tournament than in the men's tournament. Overall, women's basketball in the NCAA tournament exhibits fewer upsets and more lopsided games suggesting less overall intraseason competitive balance than the men's tournament.

Interseason competitive balance can be examined by measuring the concentration of NCAA championships. National championships will be concentrated among a low number of teams in a league exhibiting low interseason competitive balance while many different schools will have won national titles in a league with high competitive balance. ${ }^{3}$ To measure championship concentration we utilized the Herfindahl-Hirschman Index (HHI) commonly used to measure industry concentration. We calculated the HHI by squaring each school's share of the championships, adding these figures together, and multiplying by 10,000. Perfect balance for

\footnotetext{
${ }^{3}$ Focusing only on championships ignores other potential indicators of changes in competitive balance. For instance, Butler University's back-to-back runner-up finishes in the men's NCAA Tournament, cited as evidence of increasing parity (Bolch, 2011 and Weiss, 2010) would not be reflected in analysis focused on championship concentration. Nevertheless, championships are a primary focus of team sports and thus the concentration of championships is likely to be one, though certainly not the only, important indicator of competitive balance.
} 
this measure would occur if no team won multiple titles. To account for the fact that the "perfect balance" HHI will vary with the number of years under consideration, we focused on the ratio of the actual to the perfect (HHIR). This is quantitatively equivalent to summing the squares of the number of championships won by each school and dividing by the number of seasons under consideration. The lower the HHIR, the more balanced the distribution of championships. The HHIR should allow for straight-forward comparisons across leagues.

Our initial analysis covered the period over which there was both a men's and women's NCAA Division I basketball tournament (1982 through 2011). Tables 3 and 4 list the men's and women's champions for these years. These tables provide evidence of greater championship concentration in the women's game. Nineteen men's teams won at least one title compared to 14 teams on the women's side. While no men's team won more than four titles, both the Tennessee women (8) and Connecticut women (7) surpassed this mark. Table 5 further confirms that championships were more concentrated in women's college basketball. Over this period, the HHIR was 2.20 in the men's game and 4.47 in the women's game. These numbers indicate that the men's actual HHI was slightly more than twice the "perfect balance" HHI whereas the women's actual HHI was approximately four and a half times greater than the "perfect balance" HHI. This evidence of greater championship concentration in women's college basketball is consistent with the perception that men's college basketball is more competitively balanced than women's college basketball.

Further examination of men's college basketball suggests the game has grown more balanced over time. For the thirty years prior to 1982, the HHIR for men's Division I basketball was 4.40 , twice as high as the more recent thirty year period and nearly identical to the value found for women's NCAA Division I basketball during its first 30 years of existence. Extending 
the period back to 1939 , the first year of the men's NCAA tournament, only slightly reduces the HHIR to 3.98. Is there reason to believe that competitive balance in women's college basketball, as measured by championship concentration, will follow a similar pattern? The answer, perhaps, lies in the underlying determinants of the evolution of competitive balance in men's college basketball.

\section{An Explanation for Improvement: Changes in the Distribution of Player Ability}

In 1986, renowned paleontologist and baseball aficionado Stephen Jay Gould wrote a paper offering an evolution based explanation for the disappearance of the 0.400 hitter in Major League Baseball (MLB). Gould argued that the initial distribution of player ability in any sport will be widely dispersed. A small number of naturally gifted athletes will be near the limit of human capability. However, the average player will be much farther to the left in the distribution. As a sport's popularity grows and practice and training intensify, more and more players will move closer to the limit of human capability and the distribution of player ability will become more compressed. This process is illustrated in Figures 1 and 2. While the overall quality of talent in a given sport will improve over time, the gap between great and average will diminish (Gould 1986). There is anecdotal evidence consistent with this idea. Of the 35 times a MLB player has batted 0.400 or better for an entire season, only 13 occurred after 1899 and it was last accomplished by Ted Williams in 1941. In the National Basketball Association (NBA), eight of the top ten single-game individual point totals were accomplished prior to 1980 and no player has come within 13 points of Wilt Chamberlain's single season scoring record of 50.4 points per game established in 1961. Over a National Football League (NFL) career spanning 1957-1965, Jim Brown averaged 100 yards rushing per game and 5.2 yards per attempt, records that still 
stand. ${ }^{4}$ Today's elite athletes continue to produce amazing performances. However, their accomplishments may not be as rare or enduring as those of the superstars who preceded them.

Gould's idea on the evolution of the distribution of player ability has implications for competitive balance. As the divide between good and great players diminishes over time, more teams will be able to acquire the highly skilled players necessary to compete at the highest level. This assumes teams are unable to hoard great players or do not have incentives to intentionally field low quality teams. Such assumptions may not hold in professional sports. Teams in high revenue markets may have sufficient financial resources to stockpile talent. Conversely, teams in low revenue markets may earn higher profits by avoiding high priced talent. Nevertheless, there is some evidence that competitive balance may evolve over time in professional sports. Chatterjee and Yilmaz (1991) found increasing parity in Major League Baseball over time, a result confirmed by Zimbalist (1992) and several others. ${ }^{5}$ Similar to Chatterjee and Yilmaz, Zimbalist credited "the compression of baseball talent" as the "powerful leveling force" (1992, p. 97). Somewhat counterintuitively, the absence of improving balance in the National Basketball Association (NBA) may also be evidence of Gould's theory at work. Berri et al (2005) argue that because height is an important determinant of ability in professional basketball, the compression of player ability will be limited by the persistence of a relatively "short supply of tall people" (p. 1037).

The evolution of competitive balance may be even more likely in college athletics. With player compensation fixed at the value of a college education, schools with greater revenue potential are unable to lure elite players with higher salaries. Furthermore, scholarship limits

\footnotetext{
${ }^{4}$ Bo Jackson averaged 5.5 yards per rushing attempt over his career. However, he only played four seasons and thus is not credited with breaking the mark set by Jim Brown.

${ }^{5}$ See, for example, Balfour and Porter (1991), Butler (1995), Quirk and Fort (1997), Horowitz (1997), Depken (1999), and Schmidt and Berri (2001).
} 
prevent schools from hoarding talent. ${ }^{6}$ With fewer obstacles, it may be easier for the natural compression of player ability to even out the playing field in college sports relative to professional sports.

Decreasing dispersion of player ability may account for the existing differences in competitive balance in men's and women's college basketball. Opportunities to engage in competitive basketball have clearly been greater for men than women. For example, the first men's Olympic basketball tournament was held in 1936 and the first women's tournament came 40 years later. The first men's national collegiate championship, the National Invitational Tournament, was held in 1938 and it was another 34 years before the newly formed Association for Intercollegiate Athletics for Women (AIAW) crowned the first women's national collegiate champion. At the professional level, fifty years passed between the founding of the NBA in 1946 and the WNBA in 1997. With more opportunities to play basketball at various levels, men should be further along in the process of compressing player ability. Therefore, we would expect a much greater divide between elite and average players in the women's game than in the men's game. This would imply that acquiring an elite player should provide a greater advantage in the women's game than in the men's game. Recent experience is consistent with this idea. Since 1983 the Naismith Award has been presented to the player-of-the-year in men's and women's college basketball. Of the 29 female recipients, 23 were on teams that made it to the Final Four and 12 honorees came from championship teams. On the men's side, only 12 of the 29 recipients made it to the Final Four and just 3 were from the championship team. If Gould's idea regarding the evolution of player ability holds, the advantage of landing elite players should dissipate over time and women's college basketball will become more competitively balanced.

\footnotetext{
${ }^{6}$ See Berri (2004) for greater discussion on fundamental differences between college and professional sports.
} 
This argument would be further strengthened if we had some idea of whether the advantage of landing an elite player has changed in the men's game. The history of the Naismith Award is insufficient to make this type of assessment possible, but the Associated Press (AP) has been naming a player-of-the-year since 1961. Of the first 25 winners of this award, 14 came from a Final Four team and 11 of these honorees played in the championship game. Over the last 26 years, just six AP award winners have made it to the Final Four and only three played in the championship game. It appears that the potential for a great player to carry a team to the elite stage in men's basketball has diminished over time.

Examining the concentration of NCAA Division II and III basketball championships provides another test. In general, we would expect Division I schools to pick up the players on the right end of the player ability distribution while players in the middle and left end would be picked up by Division II and III schools respectively. ${ }^{7}$ As illustrated in Figure 3, this implies that Division II schools are likely to be selecting from a less widely dispersed talent pool than Division I schools. This is not true of Division III schools. However, the best players in this division are drawn from the middle of the distribution whereas the best players in Division I are drawn from the far right tail of the distribution. In other words, there is a larger supply of top Division III players than top Division I players. Consequently, we may expect greater competitive balance in both Division II and III as compared to Division I. Furthermore, while the quality of play in all divisions is likely to increase as the distribution of player ability

\footnotetext{
${ }^{7}$ Exceptions would be expected as a player's position in the distribution is not always well known before entering college. However, it does not seem unreasonable to assume that quality of play generally increases with division. Assuming absolute quality is a determinant of fan demand, attendance data may provide some insight. Per game attendance in women's Division I basketball is nearly four times higher than in Division II and roughly seven times higher than in Division III. A similar gap exists between Division II and III in men's college basketball. The gap in per game attendance between Division I and Division II is even larger in the men's game.
} 
compresses towards the biological limit, the impact on competitive balance should be greatest in

\section{Division I.}

Table 6 lists the HHIR for all three NCAA divisions in men's and women's basketball. As expected, Division I was slightly less balanced than Divisions II and III on the men's side. A similar ordering was observed in the women's game, though it appears that Division I was far more imbalanced than Division II which in turn was somewhat less balanced than Division III. Examining changes over time reveals that men's Division I experienced greater improvement in competitive balance over time than men's Division II. ${ }^{8}$ These observations all conform to predictions derived from Gould's idea on the evolution of player ability.

This section has laid out an argument that competitive balance will tend to follow a natural progression. When a sport is first taken up, competitive imbalance is to be expected due to a wide dispersion of talent. As a sport's popularity grows the imbalance will diminish as greater investment in practice and training will compress the distribution of player ability. Based on changes in the HHIR, it appears that men's NCAA Division I basketball has followed this pattern. It seems reasonable to expect that women's NCAA Division I basketball will follow a similar pattern, though there may also be reason to believe that the change will be more limited.

\section{An Accelerant: Professional Basketball}

The popularity of the NBA has increased tremendously over time. From 1970 to 2008, total attendance increased from roughly 5.5 million to approximately 21.5 million and the average NBA salary grew twentyfold from $\$ 213$ thousand to $\$ 4.8$ million in $2008 .^{9}$ The

\footnotetext{
${ }^{8}$ The period 1957-1981 was used to compare improvement in competitive balance between men's NCAA Division I and II because 1957 was the first year in which the Division II tournament was held. The NCAA Division III tournament began in 1975 which did not provide a sufficient time frame to make reasonable comparisons.

${ }^{9}$ All figures are in 2008 dollars.
} 
increasing financial returns of the NBA serve to increase competitive balance in men's college basketball in two ways. First, the potential for future fame and fortune increases the number of male athletes pursuing basketball at the youth, high school, and collegiate level serving to push the distribution of talent towards the human limit. Second, as the potential gains from playing professional basketball have escalated so too has the number of players choosing to forgo years of college eligibility to enter the NBA draft. Since 1996, 520 players have entered the NBA draft before exhausting their college eligibility, triple the annual average over the preceding twenty years. ${ }^{10}$ By luring away an increasing number of elite underclassmen the NBA further compresses the distribution of player ability in men's college basketball by removing the righthand tail of the talent distribution. ${ }^{11}$ Therefore, it is likely that the NBA has served as an accelerant for increasing competitive balance in men's NCAA Division I basketball. As Berri (2004, p. 221) notes "the ability of teams to consistently dominate college basketball is diminished".

Women's NCAA Division I basketball lacks a similar stimulant. The Women's National Basketball Association (WNBA) does not have the same pull in women's college basketball for several reasons. First, the financial rewards associated with becoming a professional women's basketball player are not large. In 2009 , the maximum rookie salary was $\$ 44,945$ and the maximum salary for any WNBA player was $\$ 99,500$. Since the WNBA does not offer its players the type of fame or financial security afforded by the NBA, fewer girls are likely to be attracted to the sport, slowing the natural progression to the limit of human ability. Second, low salaries in the WNBA or other professional women's basketball leagues in Europe mean that forgoing a college degree to begin a professional basketball career is likely to be much more

\footnotetext{
${ }^{10}$ Data on early entrants in the NBA draft were compiled from www.nbahoopsonline.com.

${ }^{11}$ Berri (2004) makes the same argument.
} 
costly for women. Lacking an attractive and plausible alternative, elite players in women's college basketball will necessarily stay in school longer than their male counterparts. Finally, the collective bargaining agreement in the WNBA bars women from entering the draft before exhausting their collegiate eligibility or turning 22 years of age, further restricting the movement of elite women's players out of the collegiate ranks. Without the allure of large salaries in professional basketball, women's NCAA Division I basketball may never reach the same level of competitive balance as men's NCAA Division I basketball.

\section{Conclusion}

Competitive balance is of great interest among sports economists and has prompted a significant amount of research in the area. Much of this literature has focused on professional sports with particular attention paid to Major League Baseball. This is not surprising given the

substantial revenues generated by major professional sports. Yet competitive balance concerns also exist in collegiate athletics and this paper contributes to the limited literature on the topic. Using several measures of competitive balance we find evidence suggestive of greater balance in men's Division I college basketball relative to women's Division I college basketball. Given the relative infancy of women's college basketball compared to the men's game, there may be reason to believe that women's Division I basketball will become more balanced as the distribution of athletic talent compresses over time. However, absent considerable growth in the popularity of women's professional basketball, competitive balance in women's Division I basketball may continue to lag that in men's Division I basketball.

Future empirical work should flesh out the degree of imbalance in college sports. The effects of imbalance in college sports are also not well understood. For example, based on 
anecdotal evidence, it is unclear the extent to which fan interest in women's college basketball has been affected by the University of Tennessee and University of Connecticut dynasties. Perhaps these dynasties have helped draw attention to a sport in its relative infancy or perhaps they are threatening to undermine its popularity. The effects of competitive imbalance on both revenue generating and non-revenue generating college sports have not yet been explored. This paper represents only a small step towards understanding competitive balance in college basketball and college athletics more generally.

Note: The authors would like to thank Stacey Hochkins for excellent research assistance. This research was also supported by generous funding from the May and Stanley Smith Charitable Trust. 


\section{REFERENCES}

Balfour, A. and P.K. Porter (1991). The reserve clause and professional sports: Legality and effect on competitive balance. Labor Law Journal, 42:1, 8-18.

Bennett, R.W. and J.L. Fizel (1995). Telecast deregulation and competitive balance: Regarding NCAA Division I football. American Journal of Economics and Sociology, 54:2, 183-189.

Berri, D. J. (2004). Is there a short supply of tall people in the college game? In J. Fizel \& R. Fort (Ed.), Economics of College Sports. Westport, CT: Praeger Publishers, 211-223.

Berri, D.J., S.L. Brook, B. Frick, A.J. Fenn, and R. Vicente-Mayoral (2005). The short supply of tall people: competitive imbalance and the National Basketball Association. Journal of Economics Issues, 39:4, 1029-1041.

Bolch, B. (2011). Basketball's controversial one-and-done rule gives college coaches fits, but changing it doesn't appear likely to be on the table at NBA labor talks. Los Angeles Times, Home Edition: Sports, May 18, 2011.

Butler, M.R. (1995). Competitive balance in Major League Baseball. American Economist, 39:2, $46-52$.

Chatterjee, S. and M.R. Yilmaz (1991). Parity in baseball: Stability of evolving systems? Chance, 4, 37-42.

Depken, C.A. (1999). Free agency and competitiveness of Major League Baseball. Review of Industrial Organization, 14, 205-217.

Depken, C.A. and D.P. Wilson (2004). Institutional change in the NCAA and competitive balance in intercollegiate football. In J. Fizel \& R. Fort (eds.), Economics of College Sports. Westport, CT: Praeger Publishers, 197-209. 
Depken, C.A. and D.P. Wilson (2006). NCAA enforcement and competitive balance in college football. Southern Economic Journal, 72:4, 826-845.

Eckard, E.W. (1998). The NCAA cartel and competitive balance in college football. Review of Industrial Organization, 13, 347-369.

Fort, R. and J. Maxcy (2003). Competitive balance in sports leagues: An introduction. Journal of Sports Economics, 4:2, 154-160.

Gould, S. J. (1986). Entopic homogeneity isn't why no one hits .400 any more. Discover Magazine, 7:8, 60-66.

Gould, S. J. (1996). Full house: The spread of excellence from Plato to Darwin. New York: Three Rivers.

Horowitz, I. (1997). The increasing competitive balance in Major League Baseball. Review of Industrial Organization, 12, 373-387.

Humphreys, B.R. (2002). Alternative Measures of Competitive Balance in Sports Leagues. Journal of Sports Economics, 3, 133-148.

Neale, W. (1964). “The Peculiar Economics of Professional Sports," Quarterly Journal of Economics, 78:1, 1-14.

Perline, M. M. and G.C. Stoldt (2007). Competitive balance in men's and women's basketball: The case of the Missouri Valley Conference. The Sport Journal. 10:4.

Quirk, J. and Fort, R. (1997). Pay dirt: The business of professional team sports. Princeton, N.J.: Princeton University Press.

Quirk, J. (2004). College football conferences and competitive balance. Managerial and Decision Science, 25, 63-75

Rottenberg, S. (1956). The baseball players' labor market. Journal of Political Economy, 64:3, 
$242-258$.

Sanderson, A. and J. Siegfried (2003). Thinking about competitive balance. Journal of Sports Economics, 4:4, 255-291.

Schmidt, M. B. and D. Berri (2001). Competition and attendance: The case of Major League Baseball. Journal of Sports Economics, 2:2, 147-167.

Sutter, D. and S. Winkler (2003). NCAA scholarship limits and competitive balance in college football. Journal of Sports Economics, 4:1, 3-18.

Weiss, D. (2010). Thank heaven Devils are in the semis. Daily News (New York), Sports Final Edition, March 29, 2010.

Zimbalist, A. (1992). Baseball and billions: A probing look inside the big business of our national pastime. Boston: Basic Books.

Zimbalist, A. (2002). Competitive balance in sports leagues - an introduction. Journal of Sports Economics, 3:2, 111-121. 
Table 1: First Round Tournament Results

\begin{tabular}{|c|c|c|c|c|}
\hline \multirow{2}{*}{ Seed } & \multicolumn{2}{|c|}{ Men's Tournament } & \multicolumn{2}{c|}{ Women's Tournament } \\
\cline { 2 - 5 } & Win Margin & Win \% & Win Margin & Win \% \\
\hline 1 & $25.84^{* * *}$ & 100.0 & $39.97^{* * *}$ & 98.6 \\
\hline 2 & $16.77^{* * *}$ & $96.2^{*}$ & $27.50^{* * *}$ & $100.0^{*}$ \\
\hline 3 & $11.53^{* * *}$ & $84.6^{* * *}$ & $19.76^{* * *}$ & $100.0^{* * *}$ \\
\hline 4 & $9.49^{* * *}$ & $78.8^{* *}$ & $16.00^{* * *}$ & $93.1^{* *}$ \\
\hline 5 & 4.54 & $66.3^{*}$ & 7.61 & $77.8^{*}$ \\
\hline 6 & 3.94 & 68.3 & 7.22 & 70.8 \\
\hline 7 & 2.20 & 58.7 & 5.36 & 65.3 \\
\hline 8 & -0.16 & 48.1 & 0.39 & 47.2 \\
\hline 9 & 0.16 & 51.9 & -0.39 & 52.8 \\
\hline 10 & -2.20 & 41.3 & -5.36 & 34.7 \\
\hline 11 & -3.94 & 31.7 & -7.22 & 29.2 \\
\hline 12 & -4.54 & $33.7^{*}$ & -7.61 & $22.2^{*}$ \\
\hline 13 & $-9.49^{* * *}$ & $21.2^{* *}$ & $-16.00^{* * *}$ & $6.9^{* *}$ \\
\hline 14 & $-11.53^{* * *}$ & $15.4^{* * *}$ & $-19.76^{* * *}$ & $0.0^{* * *}$ \\
\hline 15 & $-16.77^{* * * *}$ & $3.8^{*}$ & $-27.50^{* * *}$ & $0.0^{*}$ \\
\hline 16 & $-25.84^{* * * *}$ & 0.0 & $-39.97^{* * *}$ & 1.4 \\
\hline
\end{tabular}

*, ${ }^{* *}$, and ${ }^{* * *}$ denote statistical significance between the Men's Tournament and the Women's Tournament at the 10\%, 5\%, and 1\% levels respectively. 
Table 2: Round by round average seed remaining

\begin{tabular}{|c|c|c|c|}
\hline \multirow{2}{*}{ Round } & \multicolumn{3}{|c|}{ Average of remaining seeds } \\
\cline { 2 - 4 } & Men & Women & Idealized \\
\hline 1 & 8.50 & 8.50 & 8.5 \\
\hline 2 & 5.73 & 5.18 & 4.5 \\
\hline 3 & 4.39 & 3.42 & 2.5 \\
\hline 4 & 3.18 & 2.42 & 1.5 \\
\hline 5 & 2.55 & 2.07 & 1.0 \\
\hline 6 & 2.23 & 1.69 & 1.0 \\
\hline
\end{tabular}


Table 3: Men's NCAA Division I Champions (1982-2011)

\begin{tabular}{|l|c|}
\hline University & Year \\
\hline Arizona & 1997 \\
\hline Arkansas & 1994 \\
\hline Connecticut & $1999,2004,2011$ \\
\hline Duke & $1991,1992,2001,2010$ \\
\hline Florida & 2006,2007 \\
\hline Georgetown & 1984 \\
\hline Indiana & 1987 \\
\hline Kansas & 1988,2008 \\
\hline Kentucky & 1996,1998 \\
\hline Louisville & 1986 \\
\hline Maryland & 2002 \\
\hline Michigan & 1989 \\
\hline Michigan St. & 2000 \\
\hline North Carolina & 1985 \\
\hline North Carolina St. & $1993,2005,2009$ \\
\hline Syracuse & 1983 \\
\hline UCLA & 2003 \\
\hline UNLV & 1995 \\
\hline Villanova & 1990 \\
\hline
\end{tabular}

Source: Aggregated from the listing of champions on the NCAA webpage (http://www.ncaa.com/history/basketball-men/d1) 
Table 4: Women's NCAA Division I Champions (1982-2011)

\begin{tabular}{|l|c|}
\hline University & Year \\
\hline Baylor & 2005 \\
\hline Connecticut & 1982,1988 \\
\hline Louisiana Tech & 2006 \\
\hline Maryland & 1994 \\
\hline North Carolina & 2001 \\
\hline Notre Dame & 1985 \\
\hline Old Dominion & 1999 \\
\hline Purdue & 1983,1984 \\
\hline Southern California & 1990,1992 \\
\hline Stanford & 1986 \\
\hline Tennessee & 2011 \\
\hline Texas & 1993 \\
\hline Texas A\&M & $1987,1989,1991,1996,1997,1998,2007,2008$ \\
\hline Texas Tech & 19009,2010 \\
\hline
\end{tabular}

Source: Aggregated from the listing of champions on the NCAA webpage (http://www.ncaa.com/history/basketball-women/d1) 
Table 5: Herfindahl-Hirschman Index Ratios (HHIR) (Only Division I)

\begin{tabular}{|l|c|c|c|}
\hline Division & $\mathbf{1 9 8 2} \mathbf{- 2 0 1 1}$ & $\mathbf{1 9 5 2}-\mathbf{1 9 8 1}$ & $\mathbf{1 9 3 9} \mathbf{- 1 9 8 1}$ \\
\hline Men's NCAA Division I & 2.20 & 4.40 & 3.98 \\
\hline Women's NCAA Division I & 4.47 & n.a. & n.a. \\
\hline
\end{tabular}

Notes: For each time period the HHI was calculated by squaring the share of championships won by each school, adding these squared values together, and multiplying by 10,000. The HHIR represents the difference between this HHI and the HHI that would be obtained if no team won more than one title. Data on championships were obtained from the listing of champions on the NCAA webpages http://www.ncaa.com/history/basketball-women/dl and http://www.ncaa.com/history/basketball-men/dl. 
Table 6: Herfindahl-Hirschman Index Ratios (HHIR) (All Divisions)

\begin{tabular}{|l|c|c|}
\hline Division & $\mathbf{1 9 8 2}$ - 2011 & $\mathbf{1 9 5 7 - 1 9 8 1}$ \\
\hline Men's NCAA Division I & & \\
\hline Men's NCAA Division II & 2.20 & 4.84 \\
\hline & 1.80 & 2.28 \\
\hline Men's NCAA Division III & 1.87 & \\
\hline Womens' NCAA Division I & 4.47 & n.a. \\
\hline Womens' NCAA Division II & 2.80 & n.a. \\
\hline Womens' NCAA Division III & 1.93 & n.a. \\
\hline
\end{tabular}

Notes: For each time period the HHI was calculated by squaring the share of championships won by each school, adding these squared values together, and multiplying by 10,000. The HHIR represents the difference between this HHI and the HHI that would be obtained if no team won more than one title. Data on championships were obtained from the listing of champions on the NCAA webpages http://www.ncaa.com/history/basketball-women/d1 and http://www.ncaa.com/history/basketball-men/dl. 
Figure 1: Initial distribution of player ability

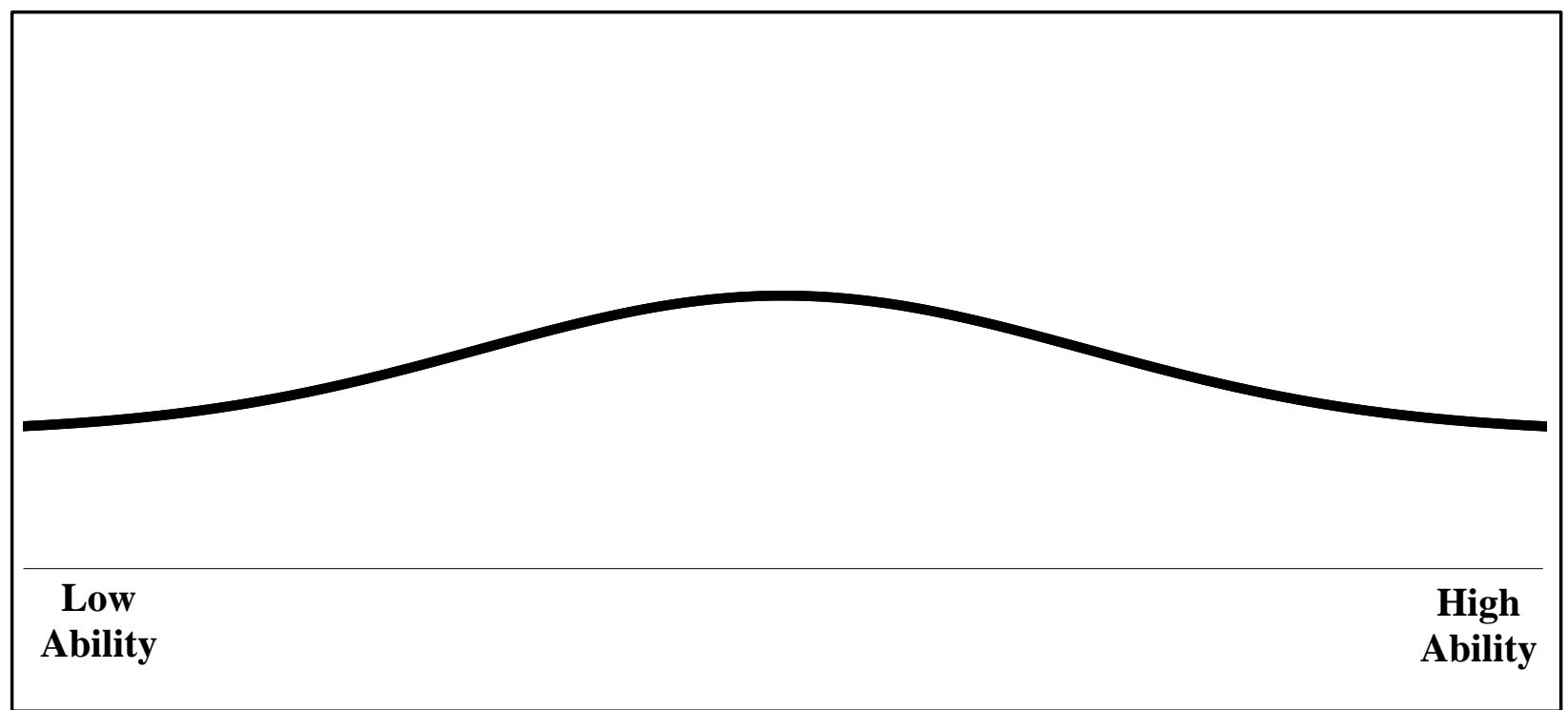

Source: Adapted from Gould (1986, 1996)

Figure 2: Distribution of player ability after years of growth in the popularity of the sport has generated greater practice and training

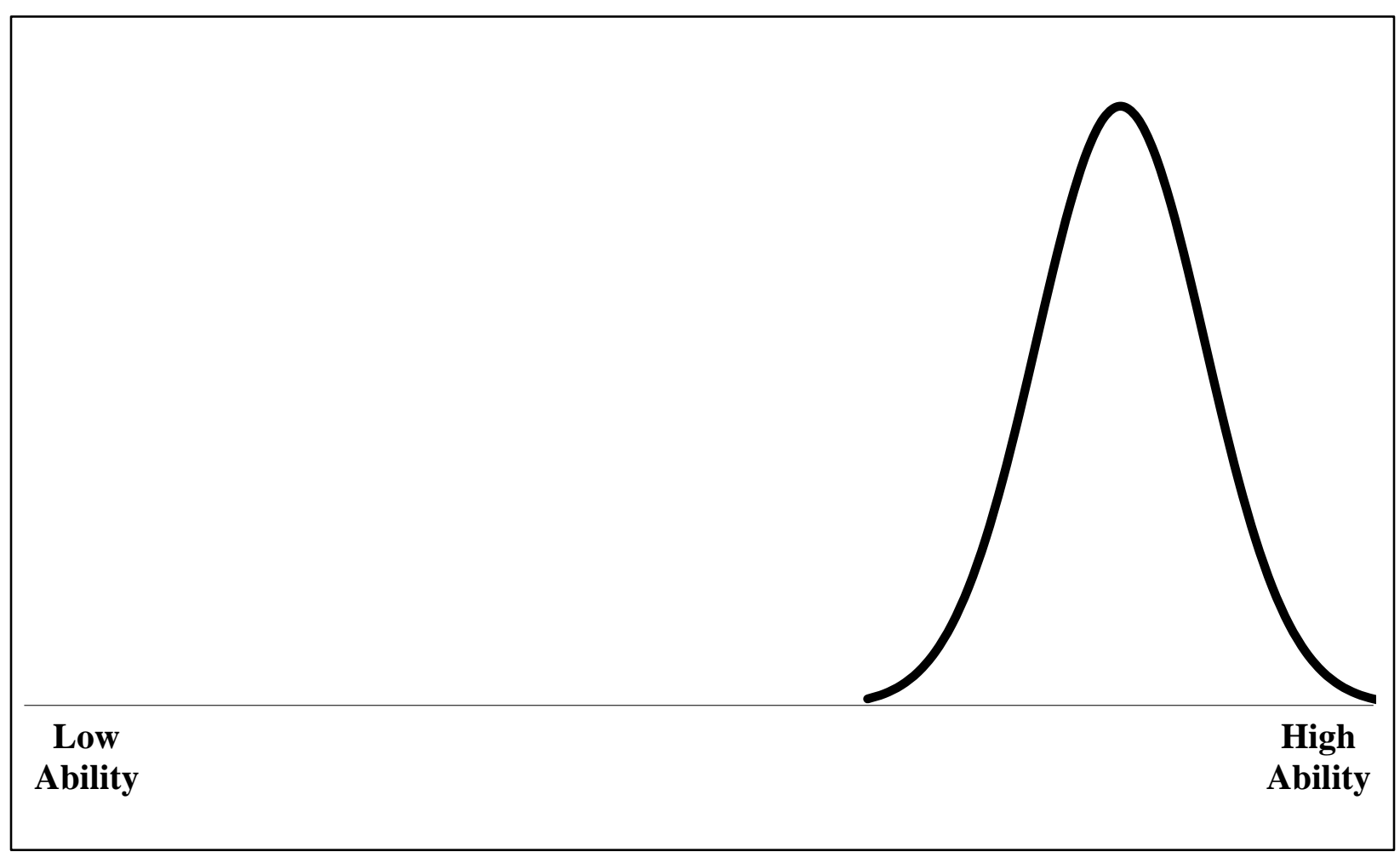

Source: Adapted from Gould (1986, 1996) 
Figure 3: Initial distribution of player ability by NCAA division

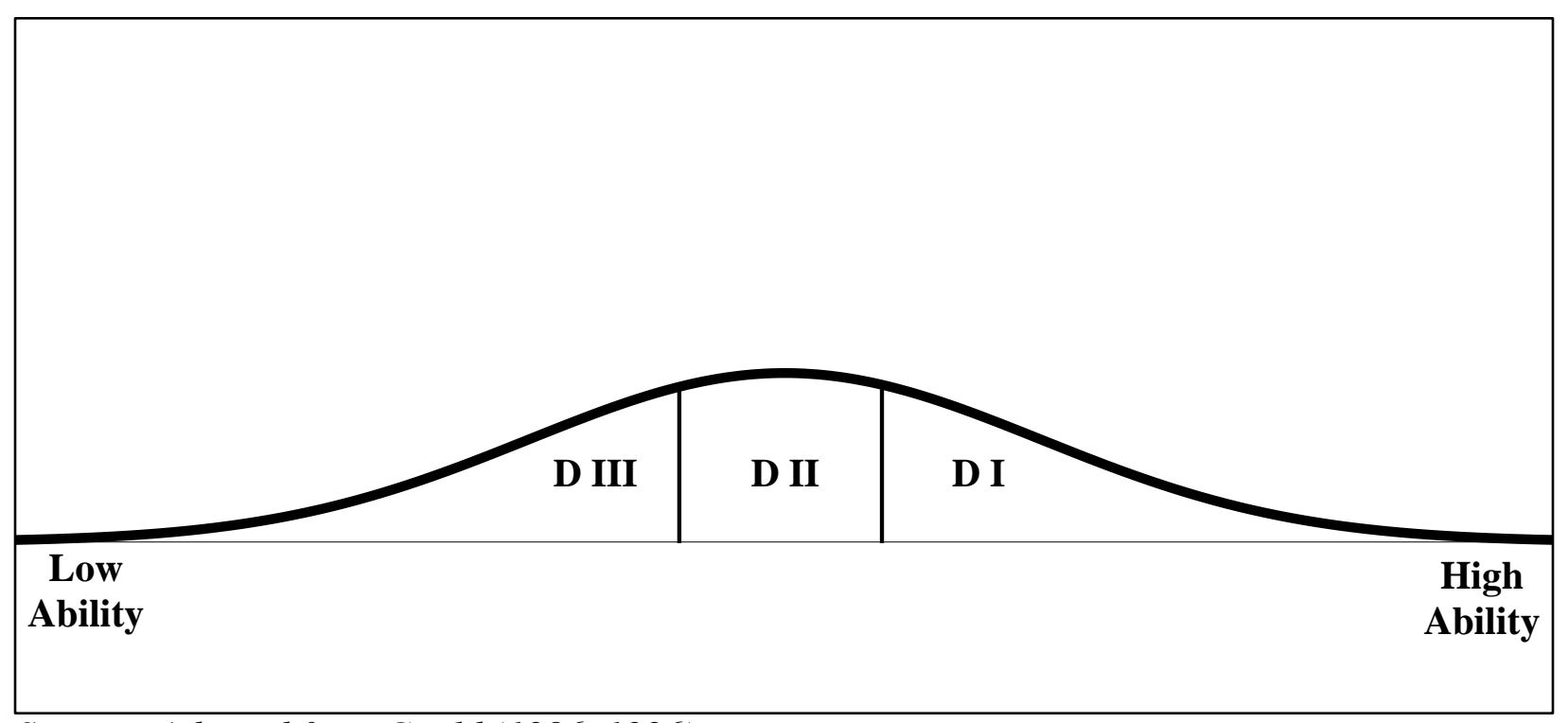

Source: Adapted from Gould (1986, 1996)

Figure 4: Distribution of player ability by NCAA division after years of growth in the popularity of the sport has generated greater practice and training

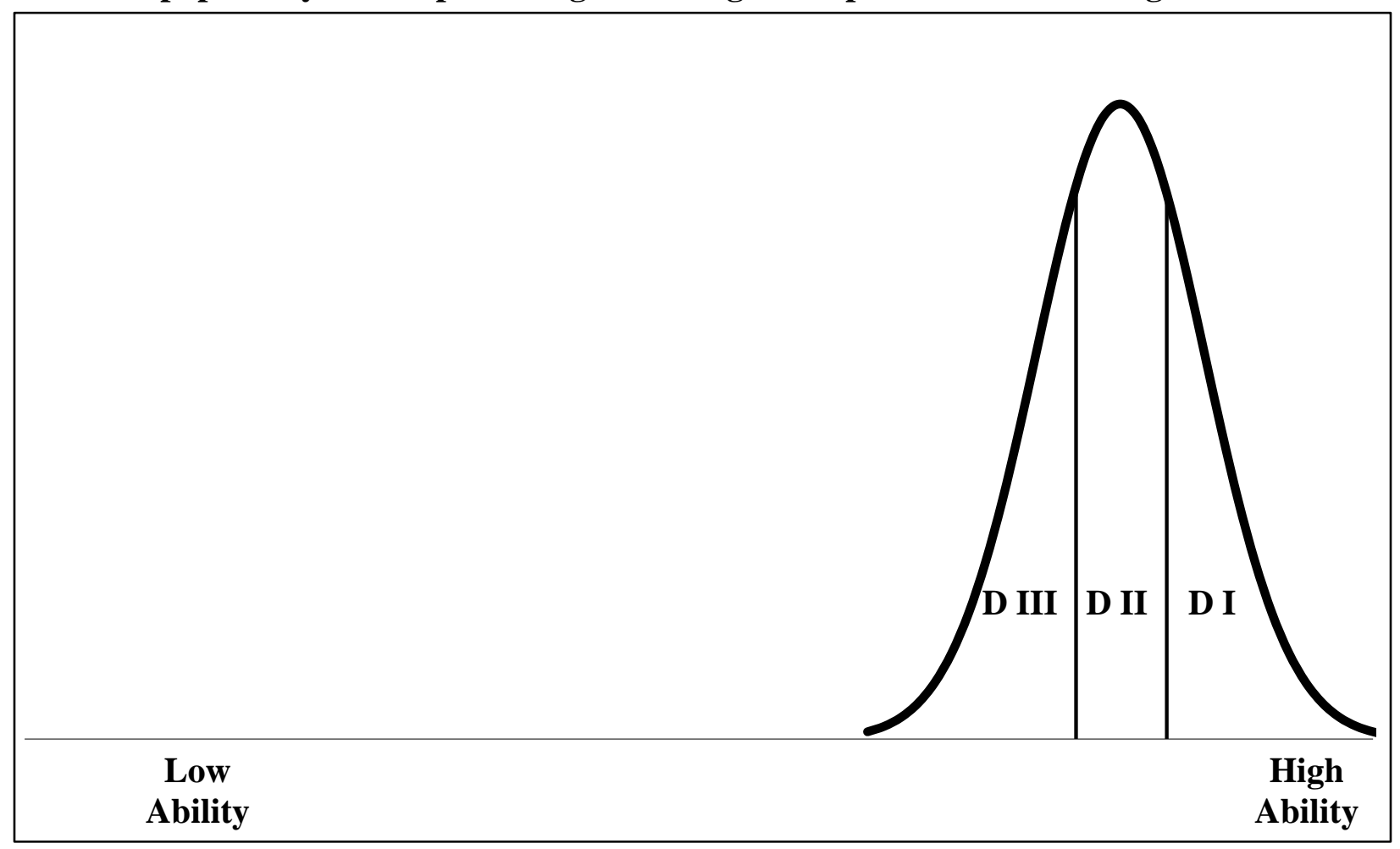

Source: Adapted from Gould (1986, 1996) 